\title{
Border, Border, Wide and Far, How We Wonder What You Are
}

\author{
David C. Parsley and Shang-Jin Wei \\ CID Working Paper No. 25
}

September 1999
(C) Copyright 1999 David C. Parsley and Shang-Jin Wei and the President and Fellows of Harvard College
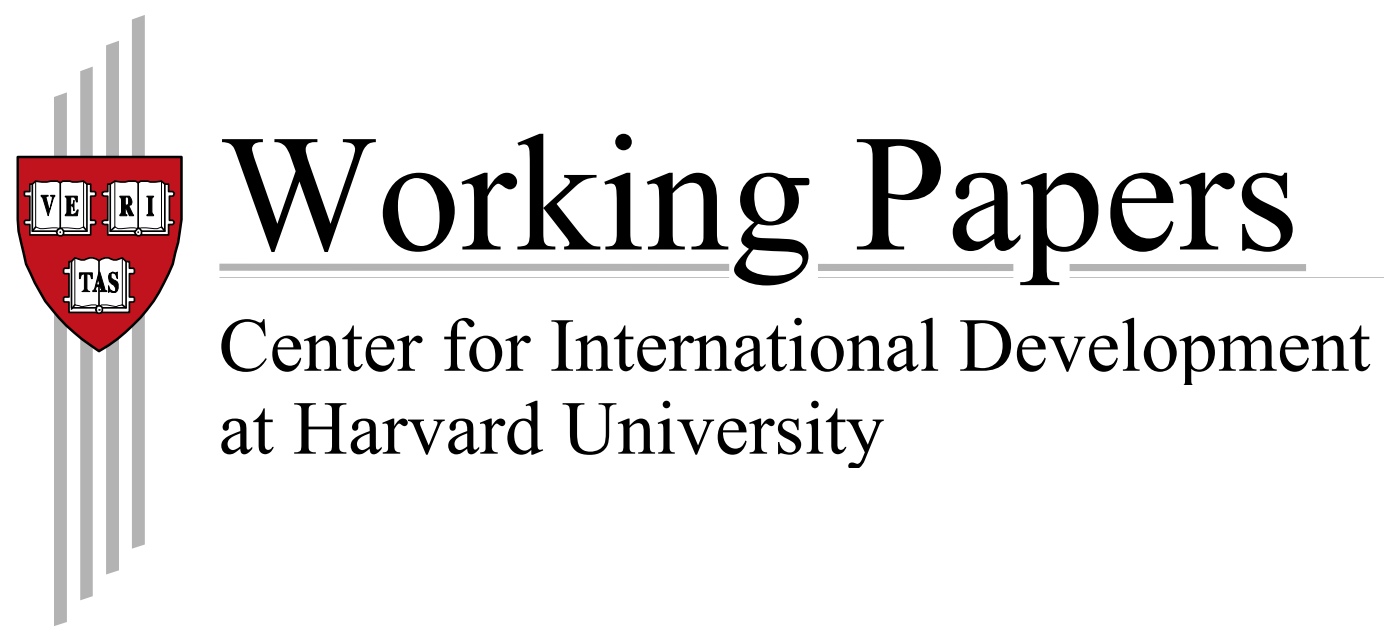


\title{
Border, Border, Wide and Far, How We Wonder What You Are
}

\author{
David C. Parsley and Shang-Jin Wei*
}

\begin{abstract}
This paper exploits a three-dimensional panel data set of prices on 27 traded goods, over 88 quarters, across 96 cities in the U.S. and Japan. We present evidence that the distribution of intranational real exchange rates is substantially less volatile and on average closer to zero, than the comparable distribution for international relative prices. We also show that an equally-weighted average of good-level real exchange rates tracks the nominal exchange rate well, suggesting strong evidence of sticky prices. We turn next to economic explanations for the dynamics of this so-called "Border" effect. Focusing on dispersion in prices between city pairs, we confirm previous findings that crossing national borders adds significantly to price dispersion. Using our point estimates crossing the U.S.-Japan "Border" is equivalent to adding between 2.5 and 13 million miles to the cross-country volatility of relative prices. We make a direct and explicit inference on the influence of shipping costs, distance, exchange rate and relative wage variability on the "Border" effect. In our calculations, the "Border" effect disappears after controlling for these additional variables.
\end{abstract}

JEL codes: F31, F36

Keywords: Law of One Price, intra-national versus international market segmentation, Border effects, good-level real exchange rates.

Shang-Jin Wei is Associate Professor of Public Policy, Harvard University and Faculty Research Fellow, National Bureau of Economic Research. E-mail: Shang-Jin_Wei@Harvard.edu

David C. Parsley, associate professor, joined the Owen Graduate School of Management faculty at Vanderbilt University, in 1990 after completing his Ph.D. at the University of California at Berkeley. Before his doctoral studies he worked for two and a half years in the research department of the Federal Reserve Bank of San Francisco. Professor Parsley's research interests are in the fields of international finance and macroeconomics. E-mail:

David.Parsley@Owen.Vanderbilt.edu

\footnotetext{
*We have benefited from comments from Mario Crucini, Jeffrey Frankel, John Rogers, Andy Rose, and other participants at the "Lessons from Intranational Economics for International Economics" conference June 11-12, 1999, and the NBER Summer Institute, July 1999.
} 


\section{Introduction}

International markets have been more segmented than intra-national markets for at least as long as the Swiss have eaten cheese. And it continues to be so today. So that is not news. The extent of segmentation, when quantitatively documented, appears striking nonetheless. In a seminal paper that looks at price volatility, Engel and Rogers (1996) showed that the dispersion of prices of similar goods increases with the distance between city pairs, a pattern that holds even within a country. However, when the price comparisons cross national political boundaries (the U.S. and Canada in their example), the dispersion of prices goes far beyond distance (and hence transportation costs): crossing the U.S.-Canada border is equivalent to crossing a distance of 75,000 miles. This is striking given that formal trade barriers between these two countries are low - and declining over time, and physical barriers to trade between the northern U.S. states and the southern Canadian provinces are presumably less important than those existing among east and west coast U.S. cities. Moreover, differences in culture and legal systems between these two countries also appear small.

Whatever the reason for the sizable "Border" effect, its existence is at least consistent with the literature on the speed of convergence to the law of one price (LOP) or purchasing power parity (PPP). Studies of convergence of real exchange rates using crosscountry evidence (e.g., Frankel and Rose, 1996, among many others) have settled down on a near-consensus of three to five years for the half-life of PPP deviations. This is in strong contrast to half-life estimates based on purely intra-U.S. prices. Parsley and Wei (1996) estimated that the half-life of deviations from the LOP is only about one year. They show that the convergence rate does slow down as the (physical) distance between price observations increases. However, despite the fact that the distance between international price observations tends to be greater than that for prices observed intra-nationally, they find that distance alone cannot explain the difference in convergence rates.

There is an analogue in studies using international trade quantity data to this pricedata-based PPP, or LOP, literature. Using the value of exports and imports, McCallum 
(1995) showed that trade between Canadian provinces is $2200 \%$ larger than between Canadian provinces and U.S. states of similar distance (and sizes). Helliwell (1998) and Wei (1996) showed that the home bias in the goods market is equally non-negligible when they examine trade between and within OECD countries.

Crucini, Telmer, and Zachariadis (1999) provide an interesting recent twist based on a large cross section of goods prices in European capital cities in 1985. They find that while the real exchange rate based on a value-weighted price index (e.g. CPI) may be far away from zero, the equally-weighted average of individual good-level log real exchange rates was actually fairly close to zero. In other words, the equally-weighted average of goods prices in local currencies between two European cities, say, Paris and Bonn, is a good predictor of the nominal exchange rate in that year. This suggests that markets (in Europe at least) may, in fact, be more integrated, and borders may matter less than studies examining the variability of price differences would suggest. Of course, among he European countries in their sample, the exchange rates were (nearly) fixed, and the physical distance and policyinduced trade barriers were low. The "Border" effect could be more significant between country pairs that do not have the same environment.

In this paper, we exploit a three-dimensional panel data set of prices for 27 commodity-level goods (e.g., one box of facial tissue, 175 count), in 88 quarters (1976:11997:4), in 96 cities in Japan and the United States. Each of the 27 goods is selected so that we can match the definition of the good reasonably well between the two countries ${ }^{1}$.

We have several objectives. First, we examine the behavior of the average goodlevel real exchange rate for the U.S. and Japan - the counterpart to the measure examined in the Crucini, et al. (1999) paper. Our data set allows us to ask two questions that the earlier paper cannot address. Does the average exchange rate between countries stray farther away from zero than that between cities within a country? And second, is there any tendency for the average exchange rate to move closer towards zero over time?

Second, we examine the infamous "Border" effect, which is related to the dispersion of the real exchange rate. The "Border" effect is defined as the extra dispersion in prices between cities in different countries beyond what can be explained by physical distance - 
the counterpart to the measure studied by Engel and Rogers (1996). ${ }^{2}$ Our innovation is on understanding its dynamics. We ask two related questions. First, is there any evidence that the "Border" narrows over time? And second, is there evidence linking the evolution of the "Border" effect with plausible economic candidates (e.g., the unit cost of international transportation)?

In contrast to Crucini, et al., we present evidence that the mean of good-level international log real exchange rates is substantially more volatile, and farther away from zero on average, than the comparable mean of intra-national log real exchange rates. We also show that the equally-weighted average of good-level real exchange rates tracks the nominal exchange rate closely. This seems to be very strong evidence of sticky prices in local currencies. We turn next to economic explanations for this so-called "Border" effect. Focusing on variability in good-level real exchange rates, we confirm previous findings that international borders matter a great deal. However, there is evidence that the "Border" effect between Japan and the U.S. declines over time in our sample. Furthermore, shipping costs, distance, exchange rate and relative wage variability collectively explain a substantial portion of the "Border" effect.

\section{Data}

Appendix Table 1 provides a brief description of the goods and their correspondence between Japan and the United States. In some cases the correspondence is remarkable given there was no single price reporting authority. In other cases we see that there is a basic, if not exact coherence in the cross-country data. The source for the Japanese data is the Annual Report on the Retail Price Survey, published by the Statistics Bureau of the Management and Coordination Agency of the Government of Japan. This print publication contains the prices of a large number of goods and services ( 700) for a sample of Japanese cities ( 70) on a monthly basis for the year. For this study we selected the first month of each quarter to obtain a time match with our U.S. data set. There is still a slight time mismatch however. The U.S. data are generally sampled seven to ten days prior to the

\footnotetext{
${ }^{1}$ A subset of the U.S. data has been examined in Parsley and Wei (1996), and O'Connell and Wei (1997).
} 
Japanese data. For every quarter in our sample (1976.1 - 1997.4), all forty-eight Japanese cities were part of the sample.

The source for the U.S. data is the Cost of Living Index published by the American Chamber of Commerce Researchers Association. This data set is described in more detail in Parsley and Wei (1996). Briefly, for this study we selected forty-eight U.S. cities and the twenty-seven traded goods most closely resembling those available in the Japanese Annual Report. Each quarterly issue of Cost of Living Index reports prices from a cross section of U.S. cities (currently exceeding 300). We selected U.S. cities that appeared in roughly 90 percent of the quarterly surveys. Appendix Table 2 lists the U.S. and Japanese cities we include. Prior to conducting our analysis we scaled the prices to further insure the units for each good were comparable.

\section{Statistical results}

\subsection{The mean of good-level real exchange rates}

Crucini et al. (1999) note that even though value-weighted average deviations from LOP over goods can be big, for the sample of European cities (in 1985) the equallyweighted average was remarkably close to zero for that year. We will see if this result is something specific to their sample of countries, which were under a fixed exchange rate arrangement, or to the particular year for which they have data.

In this paper, we focus only on those goods most clearly in the traded goods category, in part, to abstract from the Balassa-Samuelson effect. Of course, the retail price of any good could have tradable and non-tradable components. We will come back to this issue later. We attempt to limit variations in individual goods themselves through our matching process.

We choose one benchmark city from Japan and one from the United States. The benchmark cities are Tokushima for Japan, and Louisville for the United States. These are

\footnotetext{
${ }^{2}$ Of course the U.S. and Japan are not actually contiguous. We nonetheless continue to refer to the effect of international market segmentation on price dispersion as the "Border" effect.
} 
'centrally located' cities in their respective countries. This produces a sample of 189 city pairs in total.

We repeated all of the analysis of this paper using a different set of benchmark cities (Osaka and Houston) and found the results were not sensitive to this choice. Note this procedure still produces (without missing values) roughly 5100 good-level real exchange rates each period, or nearly 450,000 time-series observations. Ultimately, we study the evolution of these distributions of real exchange rates on a year-by-year basis.

Let $P(i, k, t)$ be the U.S. dollar price of good $k$ in city $i$ at time $t$. For a given city pair $(i, j)$ and a given good $k$ at a time $t$, we could define a good-level log real exchange rate

$$
r(i j, k, t)=\ln P(i, k, t)-\ln P(j, k, t) .
$$

We find it informative to study and compare the distributions of three types of good-level log exchange rates: $r(i j, k, t)$ over all city-pairs within the U.S., $r(i j, k, t)$ over all city-pairs within Japan, and $r(i j, k, t)$ over all city-pairs where city $i$ is in the U.S. and city $j$ in Japan.

Figure 1 plots the empirical kernel density estimate of the log average real exchange rate for each of our three comparisons (within Japan, within the U.S., and between the U.S. and Japan) for 1985, the same year as used by Crucini et al. (1999). Several features of the figure stand out. First, the within country densities are more closely centered on zero (a function of the benchmark city). Note that Japanese prices are less dispersed than those in the United States. This is possibly due to the relative sizes of the two countries; the greater average distance between cities in the U.S. may allow prices to vary more. Judging by this figure, deviations from the LOP within a country do not appear extraordinary. And second, the U.S.-Japan density function is centered to the left of zero. This means that in 1985 most Japanese prices were higher than U.S. prices. It also suggests the Crucini, et. al (1999) finding may be specific to Europe ${ }^{3}$.

In Figure 2, we repeat the exercise for 1990. The comparison with Figure 1 is striking. The between country distribution has diverged from the two within country

\footnotetext{
${ }^{3}$ At least two other reasons could account for the difference between our results and those in Crucini et al. (1999). First, there may be measurement errors in our data due to non-strictly comparable goods between Japan and the U.S. Additionally, we may introduce measurement error through our scaling process. That is, the price of a seven ounce bottle of shampoo is probably not seven-tenths the price of a ten ounce bottle.
} 
distributions. Japanese dollar denominated prices have risen even more relative to U.S. prices. The violation of the law of one price became even more severe.

This suggests that there may not be a trend decline in the average violation of the law of one price for traded goods. Of course, we naturally should be cautious in making a time series inference based on observations at two points in time. So we now turn to some time series evidence. Let us define the average within-U.S. log real exchange rate at time t, $\bar{r}(u s, t)$, as the average of $r(i j, k, t)$ over all goods and all city pairs within the U.S. We can define $\bar{r}($ japan,t $)$ and $\bar{r}(u s-$ japan,t $)$ in an analogous way.

The left panel of Table 1 presents, and Figure 3 plots the three average log real exchange rates over time (1976-1997), respectively. It is clear that the intra-national average log real exchange rates (or percentage deviation of prices of the same good between two cities), i.e., within both the U.S. and Japan, are fairly close to zero. In fact they vary within plus/minus 5-7 percent in each of the twenty-two years in our sample. In comparison, the average percentage deviation between U.S. and Japan makes much larger gyrations, from a minimum of $40 \%$ in 1982 to a maximum of $130 \%$ in 1995 .

We cannot fail to notice that the time series path of the average log real exchange rate between the U.S. and Japan resembles the log of the nominal yen/dollar exchange rate. We formally tested this hypothesis by regressing the first difference in the log average real exchange rate on a constant and the first difference in the log nominal exchange rate. ${ }^{4}$ In accord with our expectations, the nominal exchange rate explains much of the variation- the adjusted $\mathrm{R}^{2}$ of the equation is .49 , and the coefficient on the nominal exchange rate is estimated at 0.62 with a standard error of 0.14 . This seems to us very strong evidence that sticky prices in local currencies (as opposed to relative price of non-tradables), is a big part of CPI-based real exchange rate movements. This, from a different angle, confirms the finding in Rogers and Jenkins (1995).

This also suggests a potential reconciliation with the Crucini et al. (1999) finding. Namely, within their sample of European countries in 1985 exchange rates were tied by the European Monetary system - hence exchange rate movements were relatively small. This is

\footnotetext{
${ }^{4}$ The rate was taken from the International Financial Statistics March 1999 CD (line ae).
} 
consistent with our intra-national samples (Japan-Japan, and U.S-U.S.) evidence where nominal exchange rates are fixed. Incidentally, there is also the possibility, partly borne out by evidence presented in Figure 3, that 1985 was a special year. The deviations from the law of one price in 1985 (or any year during 1980-86) were smaller than either earlier or later years.

It may be also useful to gauge absolute deviations from the LOP. For a given citypair $(i, j)$, a given good $k$, and a time period $t$, the absolute deviation is defined as:

$$
X(i j, k, t)=|P(i, k, t)-P(j, k, t)|
$$

Let $X(u s, t)=$ the mean absolute deviation for the U.S. at time $t$ be

$$
X(u s, t)=\frac{1}{K N} \sum_{i j, k} X(i j, k, t), \text { where the sum is over all }(i, j) \text { U.S. pairs, and over all }
$$
goods $k$.

We can define $X($ japan, $t)$, and $X(u s-$ japan, $t)$ analogously. In the right-handside of Table 1, and in Figure 4, we present evidence on the mean absolute percentage deviation from the LOP. Once again, we see the same pattern. Within each country, the mean absolute deviations are between 10-15\% (somewhat larger in the United States than in Japan). However, the cross-country mean absolute deviations are several times as large, between $75 \%-140 \%$.

\section{$\underline{3.2 \text { Declining border? }}$}

We would like to understand if international market integration has increased over time (or equivalently, whether the "Border" effect has diminished). Clearly, the evidence in the previous sub-sections is that the average violation of the law of one price does not have a downward trend. However, the range in which the violation can take place, or the zone of no-arbitrage could nonetheless narrow over time. In this section, we turn to an explicit investigation of the dynamics of the "Border" effect.

The logic of no-arbitrage imposes two inequality constraints on the prices of an identical good, $k$, in two different locations, $i$ and $j$. Let $C(i j, t)$ be the cost of engaging in 
arbitrage activity for transporting and selling one unit of good $k$ from location $i$ to $j$ (or the reverse). Then, the price in one location plus the cost of arbitrage has to be at least as great as the price of the same good in another location.

$$
\ln P(i, k, t)+\ln C(i j, t) \geq \ln P(j, k, t)
$$

and

$$
\ln P(j, k, t)+\ln C(i j, t) \geq \ln P(i, k, t)
$$

Collectively, they imply that

$$
-\ln C(i j, t) \leq \ln P(i, k, t)-\ln P(j, k, t) \leq \ln C(i j, t)
$$

As long as a given price differential between the two locations satisfies these inequalities, it will not trigger arbitrage. To put it differently, within the zone of noarbitrage, the price differential can potentially take on an infinite number of possible values.

The no-arbitrage story can be made more formal. O'Connell and Wei (1997) present a continuous-time model in which an arbitrager solves an explicit optimization problem. The exact dynamics of the percentage price difference series depends on the structure of the arbitrage cost. They present three cases. In case 1, arbitrage involves a constant variable cost, but zero fixed cost (the so-called "iceberg" assumption on transport cost). The price difference follows a bounded Brownian motion process. The two bounds are determined by the variable arbitrage cost. Each time the price difference hits one of the boundaries an infinitesimal amount of arbitrage takes place to bring the difference back to just within the band. In case 2, arbitrage involves a constant fixed cost, but zero variable cost. Each time the price difference hits one of the boundaries, a discreet amount of arbitrage activity takes place to bring the price difference to the center of the no-arbitrage band (namely the point of zero price difference). And in case 3, arbitrage involves both fixed and variable cost. The price difference series can be characterized by a constrained Brownian motion process with four boundaries: two outer and two inner boundaries, both symmetric around zero. Whenever the price difference hits one of the outer boundaries, a discreet amount of arbitrage activity takes place to bring it to the closest inner boundary. 
The exact details need not concern us here. What is important for this paper is that both the simple no-arbitrage story above, and its formalization developed in O'Connell and Wei (1997) suggest that a given cost of arbitrage defines only the range in which price differences can occur, but not necessarily any particular realization of the difference. Therefore, in our empirical specification, we use as our dependent variable some measure of possible range of price differences for a given city pair. In particular, we use two measures: the standard deviation over many realizations of the log price difference, and the interquartile range between the $75^{\text {th }}$ and $25^{\text {th }}$ quartiles in the empirical distribution of all price differences between a given city pair.

\section{$\underline{3.3 \text { Results and Inferences }}$}

Let the change in the real exchange rate for good $k$ in city $i$, relative to benchmark city $j$, be

$$
Q(i j, k, t) \equiv \Delta \ln P(i, k, t)-\Delta \ln P(j, k, t) .
$$

We first present summary statistics on $Q(i j, k, t)$ in Table 2 and Figure 5. We are especially interested in intra-national versus international comparisons. In the table and figure, we report averages for Japanese-only, and U.S.-only city pairs, and we similarly average over all cross-country city pairs. Looking across the columns we see that as suggested by Figures 1 and 2, the percentage deviations within Japan or within the U.S. are smaller than for the international city pairs.

The costs of arbitrage can have many components. For example, Samuelson's (1954) "iceberg" model introduces geography in a straightforward fashion. According to this model transportation costs should depend positively on the distance between locations, so that the variation of relative prices also increases with the distance. Secondly, introducing sticky goods prices explicitly demonstrates the impact of nominal exchange rate variability on the variability of cross-country goods prices. A third important difference between intra-national and international city pairs is the potential existence of non-traded inputs (e.g., labor) and its effect on relative prices. Engel and Rogers (1996) hypothesize that relative wages are less variable within countries than they are for cross-border city pairs. 
Empirically however they find that inclusion of relative wage variability has little impact on the "Border" effect.

Our plan is to examine these and other influences on relative price variability over time. As a starting point however, we begin by reproducing the Engel-Rogers analysis of the border effect, using our U.S.-Japan data set. Engel and Rogers compute the standard deviation of $Q(i j, k, t)$ over time for each city pair and category of goods (e.g., Medical care), in their sample. They summarize the border effect by pooling the goods categories and city pairs and estimating a cross-section regression. We repeat their analysis for our data set and report the results in the first column of Table 3.

Specifically, we regress the standard deviation of the change in the real exchange rate, $V(Q(\cdot))$, on the distance between locations and a border dummy,

$$
V(Q(i j, k))=\beta_{1} \ln \left(\text { dist }_{i j}\right)+\beta_{2} \text { Border }_{i j}+\text { a constant, city, and good dummies }+\varepsilon_{i j},
$$

where dist $_{i j}$ is the greater-circle distance between cities $i$ and $j$, and Border ${ }_{i j}$ is a dummy variable that equals 1 if cities $i$ and $j$ are in different countries. The great circle distance is computed by using the latitude and longitude of each city in our sample. The source for the Japanese latitude and longitude data is the United Nations, and the source for the United States is he U.S. Naval Observatory. ${ }^{5}$ Note that this regression will have (without missing values) 5103 observations (27 goods x 189 city pairs).

The point estimates confirm that price dispersion increases with distance and that the "Border" effect is important for explaining cross-country price dispersion. We report heteroscedasticity-consistent standard errors in parentheses below the estimates. The evidence on distance however is somewhat weaker than in Engel and Rogers.

Engel and Rogers calculate that the "Border" is equivalent to adding as much as 75,000 miles does to the cross-country volatility. Performing a similar calculation, our

\footnotetext{
${ }^{5}$ The latitude and longitude information is available on the world wide web at http://www.un.org/Depts/unsd/demog/392.htm, for the Japanese data, and, http://www.touchplate.com/location.html, for the U.S. data.
} 
"Border" effect is much larger. In our case the number is roughly 6.4 trillion miles, or about 70,000 times the distance from Earth to the Sun. ${ }^{6}$

Of course, Japan and the U.S. are further apart (the actual distance between Osaka and Houston is 6,891 miles) than Canada and the U.S. In fact, the average distance between our international city pairs is over six times that between the U.S. and Canadian cities studied by Engel and Rogers; clearly, the greater separation between cities in our sample is only a small part of the story. Other candidate explanations include the fact that the yen/dollar exchange rate has been a lot more volatile than the Canadian dollar/U.S. dollar rate, and the relative wage differential is also likely to be more variable between Japan and the U.S. The question remains whether this large "Border" effect declines over time and is influenced by identifiable economic factors.

A major objective of this study is to examine the evolution of the "Border" effect. Towards that end, we examine price dispersion year-by-year. More formally, we adopt a measure of range of possible differentials that is specific to a given city-pair and year. We make it year-specific by pooling over information from the twenty-seven goods and four quarters in a given year. Recall the change in the real exchange rate (for good $k$ ) relative to benchmark city $j$ is:

$$
Q(i j, k, t) \equiv \Delta \ln P(i, k, t)-\Delta \ln P(j, k, t) \text {, where } i j \text { represents a city pair, and } t \text { is time. }
$$

Prior to calculating variability we remove the good-specific fixed effects by regressing the vector of $Q$ 's on individual good dummies (for $Q$ 's over all goods and all quarters in that year, for that city pair). Let $q(i j, k, t)$ be the residuals from that regression. We compute the standard deviation of $q$ as our measure of variability. As noted above, for robustness checks, we also adopt an alternative measure of dispersion across cities - the interquartile range $\left(75^{\text {th }}-25^{\text {th }}\right.$ fractiles of the distribution of $\left.q\right)$.

We begin our investigation of the dynamics of this "Border" effect by estimating: $V(q(i j, k, t))=\beta_{1} \ln \left(\right.$ dist $\left._{i j}\right)+\beta_{2}$ Border $_{i j}+$ a constant and city dummies $+\varepsilon_{i j, t}$.

\footnotetext{
${ }^{6}$ This is calculated as $\exp \left(\beta_{2} / \beta_{1}\right)$. Note this large distance could be a consequence of entering distance in log form.
} 
Note this regression involves 189 city pairs, each with twenty-two time periods, and individual good effects have been removed as described above.

The second column of Table 3 reports results from this regression. We again confirm that price dispersion increases with distance and that a "Border" effect exists for the U.S. and Japan. Both estimates are of the hypothesized sign and statistically significant. Using the same calculation as before the "Border" adds as much as 2.5 million miles does to the cross-country volatility.

An alternative way to compute the distance equivalent of the border effect is to ask how much extra distance do we need to add to the average distance between the two countries to generate as much price dispersion as we actually observe internationally. Suppose $Y$ is the average price dispersion between US and Japanese cities that we actually observe, then the distance equivalent of the border effect is the value of $Z$ that solves the following equation:

$$
Y=\alpha+\beta_{1} \ln (\text { distance }+Z),
$$

where $\alpha$ and $\beta_{1}$ are coefficient estimates, say from regressions reported in Table 3.

Notice that this new way of computing the distance equivalent of the border does NOT make use of the coefficient on the border dummy, but does make use of the intercept estimate. In other words, it recognizes that much of the price dispersion between locations is not explained by distance. This is true even for two locations within a country.

Of course, our regression has city dummies, so $\alpha$ is city-pair specific. We can describe an estimate to get an idea of the order of magnitude of the "Border" effect resulting from this alternative calculation. The average $\alpha$ for US-Japan pairs is roughly .1422, and the average dispersion for the US-Japan pairs given in Table 2 is .2219. Therefore, the border effect is roughly 13 million miles by this calculation. We note that while these distance calculations are somewhat less 'galactic' than that produced from the estimates in column 1, they are still huge - being between 50 and 250 times the circumference of the earth!

The next three specifications in Table 3 examine economic factors differing by country; hence they represent potential economic explanations for the "Border" effect. We 
make an attempt to measure explicitly and directly three such factors: the unit costs of transportation and insurance, the variability of nominal exchange rate, and, the variability of the relative wage differential. The Engel and Rogers paper (1996) captures the variability of the wage differential explicitly, but infers the effect of exchange rate volatility only indirectly. We present summary statistics on these variables in Table 4, and graph them in Figure 6.

One effect we should expect to be relevant for cross-country price volatility is shipping and insurance costs. We hypothesize that the log of the shipping and insurance cost is the sum of two components: one depends on the log of distance, which has already been included in the regression, and the other is the cost per unit of distance. We concentrate on the second component here. For the international part of the unit cost, we use information on the difference between c.i.f. and f.o.b. values of bilateral U.S. trade with Japan as a percentage of the total f.o.b. value. ${ }^{7}$ Specifically we collect data on (1) unit shipping and insurance costs on U.S. exports to Japan, and (2) unit shipping and insurance costs on Japanese exports to the U.S. Our measure of shipping and insurance costs is the average of (1) and (2). For the domestic (i.e., Japan only or U.S. only) part of the unit cost, we have no direct observations. In this case, we assign a value equal to one-half the minimum of the international shipping cost. This is arbitrary. However, in Table A3, we present an example based on quotes from United Parcel Service and the U.S. Postal Service that the ratio of domestic to international shipping costs over comparable distance is between .3 and .7. Additionally, we note that assigning a value of zero would overly penalize international city pairs (and hence might explain too much of the "Border" effect).

In the third column of Table 3 we add our measure of unit-shipping costs to the specification. As expected, the coefficient estimate is positive, and the estimate is highly statistically significant. Adding shipping costs improves the fit of the equation but leaves our previous conclusions with regard to the "Border" unaffected.

In the column 4 we add the variability of the differences in wages. Here we are trying to get at the non-traded component of goods prices. This variable is defined, analogous to the dependent variable, as the standard deviation of the first difference of the

\footnotetext{
${ }^{7}$ We obtained the data from various issues of the Direction of Trade publication of the IMF.
} 
$\log$ of the Japanese wage minus the first difference of the log of the U.S. wage. ${ }^{8}$ As with our shipping costs construct, we assign (an admittedly arbitrary) value of one-half the minimum of the international wage difference for the domestic part of the variability in wage differences. The coefficient on the variability of the wage difference is positive and statistically significant. Moreover, adding this variable to our equation reduces the "Border" effect substantially. Now, crossing the "Border" adds slightly less than an additional 20,000 miles.

The final economic variable we want to introduce is exchange rate volatility. Exchange rate volatility is defined as the standard deviation of daily changes in the (log) nominal exchange rate as an additional regressor. ${ }^{9}$ As expected, exchange rate volatility has a positive and significant effect on cross-country price dispersion. More significantly however, is that the estimate of the "Border" declines sharply - in fact, the "Border" effect becomes negative.

We are concerned that other omitted factors may be influencing these results. In the final column we add four more control variables: a linear trend, the trend interacted with the border and with distance, and a squared log distance term. Each of these new regressors is statistically significant. In this specification the coefficient on the border dummy now captures the "Border" effect at the beginning of our sample, 1976. The negative estimate for the trend/border interaction term suggests that the "Border" effect is declining over time, albeit slowly. Only two coefficient estimates change noticeably with the introduction of these control variables. First, notice that the point estimate on log distance has risen but remains statistically significant. Now however, the estimate of the "Border" has moved closer to zero and becomes insignificant.

It is important to know if any of this is robust against more scrutiny. We turn next to some robustness checks.

\footnotetext{
${ }^{8}$ The source for this data is also the March 1999 IFS CD (lines 65 for Japan, and 65ey for the U.S.).

${ }^{9}$ The source for the daily exchange rate data is the St. Louis Federal Reserve web site. Using daily data permits more precise estimates of exchange rate variability. However, we have compared this to variability computed using monthly data. Aside from a scale difference, time series plots of these two variability measures are virtually indistinguishable.
} 


\section{$\underline{3.4 \text { Extensions and Robustness checks }}$}

There is a concern that exchange rate volatility, wage volatility, and unit shipping and insurance costs may be over-estimated due to correlated errors. In the regressions so far, we stack data for different city pairs. Correlated errors across city pairs for the same year could lead to underestimated standard errors. In an effort to deal with this issue we implement systems estimation using the seemingly unrelated regressions method.

We select the first ten international city pairs containing no missing values using the Tokushima and Louisville benchmark. Thus the resulting system has twenty equations. ${ }^{10}$ We allow the intercept to be different in each equation, and hence, to be different for each city-pair. We impose the restriction that the coefficients on all other regressors are the same. With this specification, all time invariant and city pair specific effects (e.g., distance and border effects) will be absorbed in the intercept.

In Table 5 we proceed sequentially as before beginning with shipping costs. The point estimate is even larger than that in the OLS regressions, and it is still positive and statistically significant. In column 2 , we add exchange rate volatility. The coefficient on this variable is essentially the same as before. In the final column we add wage variability. Again, the coefficient estimate on wage variability is essentially the same as before and statistically significant. Thus we conclude that each of these economic determinants is important to understanding the "Border" effect.

We try two more extensions to test the robustness of our results. First, we repeat the analysis using the interquartile range $\left(75^{\text {th }}-25^{\text {th }}\right.$ percentiles of the distribution) of our real exchange rate variability measure. These results are presented in Table 6.

A second robustness test was to repeat the analysis using two different benchmark cities. We selected Osaka and Houston, partly because Houston, like Louisville had only two quarters of missing values, and partly because we wanted to select larger, coastal cities for the analysis. These results are reported in Table 7.

The basic findings reported earlier are qualitatively valid in these alternative definitions of the dependent variable, alternative estimation method, and alternative choice

\footnotetext{
${ }^{10}$ Using all city pairs would lead to a singular variance-covariance matrix.
} 
of the benchmark cities. In particular, the border effect adds significantly to price dispersion. However, sequentially adding shipping costs, relative wage volatility, and exchange rate volatility produces a smaller and smaller coefficient on the border dummy.

\section{Concluding remarks}

This paper exploits a three-dimensional panel data set of prices on 27 traded goods, over 88 quarters, across 96 cities in the U.S. and Japan. We present evidence that the distribution of intra-national real exchange rates is substantially less volatile and on average closer to zero, than the comparable distribution for international relative prices. We also show that an equally-weighted average of good-level real exchange rates tracks the nominal exchange rate well, suggesting strong evidence of sticky prices.

We turn next to economic explanations for the dynamics of this so-called "Border" effect. Focusing on dispersion in prices between city pairs, we confirm previous findings that crossing national borders adds significantly to price dispersion. Using our point estimates crossing the U.S.-Japan "Border" is equivalent to adding between 2.5 and 13 million miles to the cross-country volatility of relative prices. We make a direct and explicit inference on the influence of shipping costs, distance, exchange rate and relative wage variability on the "Border" effect. In our calculations, the "Border" effect disappears after controlling for these additional variables. 


\section{REFERENCES}

Balassa, Bela, 1964, "The Purchasing-Power parity Doctrine: A Reappraisal," Journal of Political Economy, pp. 584-96.

Crucini, Mario, Chris Telmer, and Marios Zachariadis, 1999, "Dispersion in International Prices", University of Pennsylvania working paper.

Engel, Charles, 1993, "Real Exchange Rates and Relative Prices: An Empirical Investigation," Journal of Monetary Economics, 32:35-50.

Engel, Charles, and John Rogers, 1996, "How Wide is the Border?" American Economic Review, 86:5, pp. 1112-1125.

Frankel, Jeffrey, and Andrew Rose, 1996, "A Panel Project on Purchasing Power Parity: Mean Reversion within and between Countries", Journal of International Economics, 40:1-2, pp. 209-224.

Froot, Kenneth, and Kenneth Rogoff, 1995, "Perspectives on PPP and Long-Run Real Exchange Rates," Handbook of International Economics, Volume 3. New York, Elsevier, pp. 1647-1688.

Helliwell, John, 1998, How Much Do National Borders Matter? DC: Brookings Institution Press.

O'Connell, Paul, and Shang-Jin Wei, 1997, "The Bigger They Are, The Harder They Fall: How Price Differences Across U.S. Cities Are Arbitraged?” NBER Working Paper 6089, July.

Parsley, David, and Shang-Jin Wei, 1996, "Convergence to the Law of One Price without Trade Barriers or Currency Fluctuations", Quarterly Journal of Economics, 111:4, pp. 1211-36.

Rogers, John, and Michael Jenkins, 1994, "Haircuts of Hysteresis? Sources of Movements in Real Exchange Rates, Journal of International Economics, 38 (3-4), May 1995, pages $339-60$

Samuelson, Paul, 1954, "Theoretical Notes on Trade Problem," Review of Economics and Statistics, 46: 145-164.

Statistics Bureau, Management and Coordination Agency, Government of Japan, Annual

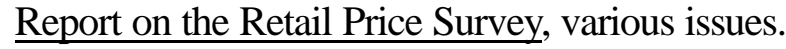

The American Practical Navigator, 1977, Volume 1: Washington: U.S. Defense Mapping Agency.

Wei, Shang-jin, 1996, "Intra-national versus International Trade: How Stubborn Are Nations in Global Integration?” NBER Working Paper 5531, April. 
Table 1. Measures of Intra-national and International Price Deviations (Simple Average over Traded Goods and City Pairs)

Average of Good-Level Average of Good-Level

Log Real Exchange Rates Absolute Percentage Deviations

\begin{tabular}{lrrrrrr} 
Year & Japan & \multicolumn{1}{l}{ U.S. } & U.S -Japan & Japan & U.S. & U.S. Japan \\
\hline 1976 & 0.0312 & -0.0267 & -0.9617 & 0.1230 & 0.1494 & 0.9968 \\
1977 & 0.0125 & -0.0463 & -0.9885 & 0.1111 & 0.1406 & 1.0315 \\
1978 & 0.0228 & -0.0240 & -0.9713 & 0.1195 & 0.1276 & 1.2087 \\
1979 & 0.0227 & -0.0388 & -0.7251 & 0.1105 & 0.1105 & 0.9866 \\
1980 & -0.0054 & -0.0185 & -0.6738 & 0.1072 & 0.1167 & 0.9661 \\
1981 & -0.0021 & -0.0418 & -0.7369 & 0.1036 & 0.1368 & 1.0010 \\
1982 & 0.0135 & 0.0215 & -0.3997 & 0.0949 & 0.1229 & 0.7805 \\
1983 & 0.0304 & -0.0066 & -0.4518 & 0.1055 & 0.1227 & 0.7889 \\
1984 & 0.0425 & -0.0102 & -0.4279 & 0.1047 & 0.1326 & 0.7662 \\
1985 & 0.0110 & -0.0096 & -0.4405 & 0.1300 & 0.1453 & 0.7967 \\
1986 & -0.0053 & 0.0157 & -0.7256 & 0.1262 & 0.1272 & 0.9892 \\
1987 & -0.0181 & -0.0036 & -0.8221 & 0.1266 & 0.1465 & 1.0568 \\
1988 & -0.0304 & -0.0080 & -0.9454 & 0.1234 & 0.1416 & 1.1606 \\
1989 & -0.0220 & -0.0044 & -0.8720 & 0.1260 & 0.1379 & 1.0930 \\
1990 & 0.0125 & 0.0595 & -0.8949 & 0.1131 & 0.1498 & 1.1171 \\
1991 & 0.0008 & 0.0523 & -0.9954 & 0.1065 & 0.1727 & 1.1939 \\
1992 & 0.0259 & 0.0618 & -1.0900 & 0.1130 & 0.1591 & 1.2682 \\
1993 & 0.0187 & 0.0587 & -1.2123 & 0.1065 & 0.1561 & 1.3657 \\
1994 & 0.0034 & 0.0308 & -1.2523 & 0.1055 & 0.1436 & 1.3920 \\
1995 & 0.0160 & 0.0440 & -1.3056 & 0.1115 & 0.1506 & 1.3953 \\
1996 & 0.0045 & 0.0665 & -1.2036 & 0.1153 & 0.1523 & 1.2183 \\
1997 & 0.0045 & 0.0361 & -1.0406 & 0.1135 & 0.1549 & 1.1801 \\
& & & & & & \\
Average & 0.0086 & 0.0095 & -0.8699 & 0.1135 & 0.1408 & 1.0797 \\
& & & & & & \\
\hline
\end{tabular}


Table 2. Variability in Relative Prices

Tokushima-Louisville benchmark city

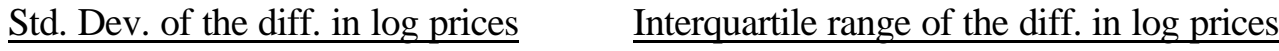

\begin{tabular}{lcccccc} 
Year & Japan only & U.S. only & U.S-Japan & Japan only & U.S. only & U.S.-Japan \\
\hline 1976 & 0.1541 & 0.1828 & 0.2264 & 0.0548 & 0.1945 & 0.2061 \\
1977 & 0.1238 & 0.1836 & 0.2139 & 0.0436 & 0.1721 & 0.1977 \\
1978 & 0.1167 & 0.1638 & 0.3596 & 0.0358 & 0.1587 & 0.2540 \\
1979 & 0.1261 & 0.1567 & 0.3166 & 0.0282 & 0.1552 & 0.1702 \\
1980 & 0.1378 & 0.1502 & 0.2850 & 0.0704 & 0.1459 & 0.2102 \\
1981 & 0.1332 & 0.1375 & 0.2545 & 0.0507 & 0.1445 & 0.1861 \\
1982 & 0.1120 & 0.1431 & 0.2431 & 0.0315 & 0.1511 & 0.1736 \\
1983 & 0.1171 & 0.1355 & 0.1766 & 0.0409 & 0.1467 & 0.1764 \\
1984 & 0.1169 & 0.1270 & 0.1667 & 0.0311 & 0.1445 & 0.1525 \\
1985 & 0.1262 & 0.1630 & 0.1805 & 0.0549 & 0.1489 & 0.1709 \\
1986 & 0.0897 & 0.1593 & 0.2021 & 0.0426 & 0.1596 & 0.1443 \\
1987 & 0.0974 & 0.1634 & 0.2096 & 0.0415 & 0.1550 & 0.1605 \\
1988 & 0.0938 & 0.1604 & 0.2105 & 0.0377 & 0.1500 & 0.2081 \\
1989 & 0.1004 & 0.1499 & 0.2065 & 0.0600 & 0.1552 & 0.1753 \\
1990 & 0.1073 & 0.1696 & 0.2608 & 0.0788 & 0.1773 & 0.2295 \\
1991 & 0.0929 & 0.1773 & 0.1857 & 0.0630 & 0.1728 & 0.1690 \\
1992 & 0.1222 & 0.1672 & 0.1826 & 0.0733 & 0.1665 & 0.1793 \\
1993 & 0.1236 & 0.1431 & 0.1579 & 0.0687 & 0.1459 & 0.1534 \\
1994 & 0.1257 & 0.1430 & 0.2089 & 0.0709 & 0.1418 & 0.1910 \\
1995 & 0.1142 & 0.1747 & 0.2165 & 0.0766 & 0.1580 & 0.2438 \\
1996 & 0.1173 & 0.1428 & 0.2059 & 0.0841 & 0.1539 & 0.1411 \\
1997 & 0.0955 & 0.1940 & 0.2132 & 0.0724 & 0.2041 & 0.2035 \\
& & & & & & \\
Average & 0.1156 & 0.1585 & 0.2219 & 0.0551 & 0.1592 & 0.1862 \\
& & & & & & \\
\hline
\end{tabular}


Table 3. Explaining the Border Effect

Dependent Variable: Standard Deviation of Log Price Differential

Tokushima-Louisville Benchmark cities

\begin{tabular}{|c|c|c|c|c|c|c|}
\hline Log Distance & $\begin{array}{r}\text { Equation } \frac{1}{1} \\
0.0022 \\
(0.0017)\end{array}$ & $\begin{array}{r}\text { Equation } \\
0.0049 \\
(0.0018)\end{array}$ & $\begin{array}{r}\text { Equation } \\
0.0049 \\
(0.0018)\end{array}$ & $\begin{array}{r}\text { Equation } \\
0.0052 \\
(0.0016)\end{array}$ & $\begin{array}{r}\text { Equation } 5 \\
0.0052 \\
(0.0014)\end{array}$ & $\begin{array}{r}\text { Equation } \mathbf{6} \\
0.0226 \\
(0.0104)\end{array}$ \\
\hline Border & $\begin{array}{r}0.0649 \\
(0.0055)\end{array}$ & $\begin{array}{r}0.0717 \\
(0.0058)\end{array}$ & $\begin{array}{r}0.0717 \\
(0.0057)\end{array}$ & $\begin{array}{r}0.0511 \\
(0.0050)\end{array}$ & $\begin{array}{r}-0.0524 \\
(0.0056)\end{array}$ & $\begin{array}{r}-0.0151 \\
(0.0109)\end{array}$ \\
\hline Shipping Costs & & & $\begin{array}{r}0.5215 \\
(0.0375)\end{array}$ & $\begin{array}{r}0.2368 \\
(0.0341)\end{array}$ & $\begin{array}{r}0.1595 \\
(0.0304)\end{array}$ & $\begin{array}{r}0.1671 \\
(0.0304)\end{array}$ \\
\hline Wage Variability & & & & $\begin{array}{r}1.8125 \\
(0.0553)\end{array}$ & $\begin{array}{r}2.1278 \\
(0.0501)\end{array}$ & $\begin{array}{r}1.6722 \\
(0.0716)\end{array}$ \\
\hline $\begin{array}{l}\text { Nominal Exchange } \\
\text { Rate Variability }\end{array}$ & & & & & $\begin{array}{l}16.2286 \\
(0.5151)\end{array}$ & $\begin{array}{r}17.2132 \\
(0.5193)\end{array}$ \\
\hline Trend & & & & & & $\begin{array}{r}-0.0022 \\
(0.0008)\end{array}$ \\
\hline Trend*Log Distance & & & & & & $\begin{array}{r}0.0003 \\
(0.0001)\end{array}$ \\
\hline Trend* Border & & & & & & $\begin{array}{r}-0.0020 \\
(0.0005)\end{array}$ \\
\hline $\begin{array}{l}\text { Log distance } \\
\text { Squared }\end{array}$ & & & & & & $\begin{array}{r}-0.0018 \\
(0.0009)\end{array}$ \\
\hline $\begin{array}{l}\text { Adjusted } R^{2} \\
\text { N. of observations }\end{array}$ & $\begin{array}{r}0.78 \\
5065\end{array}$ & $\begin{array}{r}0.53 \\
3820\end{array}$ & $\begin{array}{r}0.55 \\
3820\end{array}$ & $\begin{array}{r}0.65 \\
3820\end{array}$ & $\begin{array}{r}0.73 \\
3820\end{array}$ & $\begin{array}{r}0.73 \\
3820\end{array}$ \\
\hline
\end{tabular}


Table 4. Shipping Costs, Exchange Rate Variability, and Wage Variability

\begin{tabular}{|c|c|c|c|}
\hline$\underline{\text { Year }}$ & $\underline{\text { Shipping Costs }}$ & Exchange Rate Variability & Wage Variability \\
\hline$\overline{1976}$ & 0.1088 & 0.0021 & 0.0536 \\
\hline 1977 & 0.0877 & 0.0036 & 0.0545 \\
\hline 1978 & 0.0950 & 0.0082 & 0.0513 \\
\hline 1979 & 0.1033 & 0.0066 & 0.0419 \\
\hline 1980 & 0.0999 & 0.0074 & 0.0635 \\
\hline 1981 & 0.0864 & 0.0070 & 0.0480 \\
\hline 1982 & 0.1157 & 0.0076 & 0.0251 \\
\hline 1983 & 0.0647 & 0.0051 & 0.0196 \\
\hline 1984 & 0.0652 & 0.0043 & 0.0207 \\
\hline 1985 & 0.1123 & 0.0058 & 0.0184 \\
\hline 1986 & 0.0660 & 0.0071 & 0.0076 \\
\hline 1987 & 0.0793 & 0.0065 & 0.0089 \\
\hline 1988 & 0.0742 & 0.0064 & 0.0183 \\
\hline 1989 & 0.0561 & 0.0069 & 0.0156 \\
\hline 1990 & 0.0526 & 0.0066 & 0.0251 \\
\hline 1991 & 0.0690 & 0.0061 & 0.0224 \\
\hline 1992 & 0.0632 & 0.0053 & 0.0169 \\
\hline 1993 & 0.0933 & 0.0070 & 0.0182 \\
\hline 1994 & 0.0981 & 0.0056 & 0.0142 \\
\hline 1995 & 0.1035 & 0.0088 & 0.0160 \\
\hline 1996 & 0.1048 & 0.0048 & 0.0222 \\
\hline 1997 & 0.0971 & 0.0072 & 0.0195 \\
\hline Average & 0.0862 & 0.0062 & 0.0273 \\
\hline
\end{tabular}

Shipping Costs are defined as the average percentage difference between the value of U.S. imports from Japan on a c.i.f. basis and an f.o.b. basis, and the value of Japanese imports from the U.S. on a c.i.f. basis and an f.o.b. basis.

Exchange Rate Variability is defined as the standard deviation over the year of $\ln \left(\mathrm{x}_{\mathrm{t}}\right)-\ln \left(\mathrm{x}_{\mathrm{t}-1}\right)$ Wage Variability is defined as the standard deviation of $d \ln \left(\right.$ wage $\left._{\mathrm{j}}\right)$-dln $\left(\right.$ wage $\left._{\mathrm{us}}\right)$ 
Table 5. Robustness Checks: SUR Estimation Tokushima-Louisville Benchmark

\begin{tabular}{|c|c|c|c|}
\hline Shipping Costs & $\begin{array}{l}\frac{\text { Equation }}{2.2932} \\
(0.2555)\end{array}$ & $\begin{array}{c}\frac{\text { Equation }}{3.2870} \\
2 \\
(0.1146)\end{array}$ & $\begin{array}{l}\frac{\text { Equation }}{0.8198} \\
(0.0596)\end{array}$ \\
\hline $\begin{array}{l}\text { Nominal Exchange } \\
\text { Rate Variability }\end{array}$ & & $\begin{array}{r}17.7292 \\
(0.6079)\end{array}$ & $\begin{array}{r}16.9050 \\
(0.2419)\end{array}$ \\
\hline Wage Variability & & & $\begin{array}{r}1.8105 \\
(0.0282)\end{array}$ \\
\hline $\begin{array}{l}\text { Average adjusted } R^{2} \\
\text { N. of equations } \\
\text { N. of observations }\end{array}$ & $\begin{array}{l}.052 \\
20 \\
440(=20 \times 22)\end{array}$ & .272 & .493 \\
\hline
\end{tabular}

Note: equation specific intercepts not reported. 
Table 6. Explaining the Border Effect

Dependent Variable: Interquartile Range of Log Price Differential

Tokushima-Louisville Benchmark cities

\begin{tabular}{|c|c|c|c|c|c|c|}
\hline Log Distance & $\begin{array}{r}\text { Equation } 1 \\
0.0016 \\
(0.0023)\end{array}$ & $\begin{array}{r}\text { Equation } 2 \\
0.0022 \\
(0.0016)\end{array}$ & $\begin{array}{r}\text { Equation } \\
0.0022 \\
(0.0016)\end{array}$ & $\begin{array}{r}\text { Equation } \\
0.0023 \\
(0.0016)\end{array}$ & $\begin{array}{r}\text { Equation } \\
0.0024 \\
(0.0015)\end{array}$ & $\begin{array}{r}\text { Equation } \\
0.0056 \\
(0.0113)\end{array}$ \\
\hline Border & $\begin{array}{r}0.0911 \\
(0.0074)\end{array}$ & $\begin{array}{r}0.0728 \\
(0.0051)\end{array}$ & $\begin{array}{r}0.0728 \\
(0.0051)\end{array}$ & $\begin{array}{r}0.0636 \\
(0.0050)\end{array}$ & $\begin{array}{r}0.0170 \\
(0.0060)\end{array}$ & $\begin{array}{r}-0.0035 \\
(0.0118)\end{array}$ \\
\hline Shipping Costs & & & $\begin{array}{r}0.1142 \\
(0.0334)\end{array}$ & $\begin{array}{c}-0.0144 \\
(0.0336)\end{array}$ & $\begin{array}{c}-0.0494 \\
(0.0329)\end{array}$ & $\begin{array}{r}-0.0355 \\
(0.0328)\end{array}$ \\
\hline Wage Variability & & & & $\begin{array}{r}0.8144 \\
(0.0542)\end{array}$ & $\begin{array}{r}0.9562 \\
(0.0541)\end{array}$ & $\begin{array}{r}1.2967 \\
(0.0772)\end{array}$ \\
\hline $\begin{array}{l}\text { Nominal Exchange } \\
\text { Rate Variability }\end{array}$ & & & & & $\begin{array}{r}7.2913 \\
(0.5558)\end{array}$ & $\begin{array}{r}6.5053 \\
(0.5597)\end{array}$ \\
\hline Trend & & & & & & $\begin{array}{r}0.0039 \\
(0.0083)\end{array}$ \\
\hline Trend*Log Distance & & & & & & $\begin{array}{r}-0.0005 \\
(0.0001)\end{array}$ \\
\hline Trend* Border & & & & & & $\begin{array}{r}0.0017 \\
(0.0005)\end{array}$ \\
\hline $\begin{array}{l}\text { Log distance } \\
\text { Squared }\end{array}$ & & & & & & $\begin{array}{r}0.0002 \\
(0.0010)\end{array}$ \\
\hline $\begin{array}{l}\text { Adjusted } R^{2} \\
\text { N. of observations }\end{array}$ & $\begin{array}{r}0.78 \\
5065\end{array}$ & $\begin{array}{r}0.67 \\
3842\end{array}$ & $\begin{array}{r}0.67 \\
3842\end{array}$ & $\begin{array}{r}0.69 \\
3842\end{array}$ & $\begin{array}{r}0.71 \\
3842\end{array}$ & $\begin{array}{r}0.72 \\
3842\end{array}$ \\
\hline
\end{tabular}


Table 7. Explaining the Border Effect

Dependent Variable: Standard Deviation of Log Price Differential Osaka-Houston Benchmark Cities

\begin{tabular}{|c|c|c|c|c|c|c|}
\hline Log Distance & $\begin{array}{r}\text { Equation } 1 \\
0.0031 \\
(0.0017)\end{array}$ & $\begin{array}{r}\text { Equation } 2 \\
0.0057 \\
(0.0017)\end{array}$ & $\begin{array}{r}\text { Equation } \mathbf{3} \\
0.0057 \\
(0.0017)\end{array}$ & $\begin{array}{r}\text { Equation } \\
0.005 \\
(0.0015)\end{array}$ & $\begin{array}{r}\text { Equation } \mathbf{5} \\
0.0055 \\
(0.0013)\end{array}$ & $\begin{array}{r}\text { Equation } \\
0.0099 \\
(0.0072)\end{array}$ \\
\hline Border & $\begin{array}{r}0.0695 \\
(0.0052)\end{array}$ & $\begin{array}{r}0.0753 \\
(0.0051)\end{array}$ & $\begin{array}{r}0.0753 \\
(0.0050)\end{array}$ & $\begin{array}{r}0.0606 \\
(0.0046)\end{array}$ & $\begin{array}{l}-0.0388 \\
(0.0052)\end{array}$ & $\begin{array}{r}-0.0322 \\
(0.0111)\end{array}$ \\
\hline Shipping Costs & & & $\begin{array}{r}0.4345 \\
(0.0349)\end{array}$ & $\begin{array}{r}0.2060 \\
(0.0330)\end{array}$ & $\begin{array}{r}0.1312 \\
(0.0294)\end{array}$ & $\begin{array}{r}0.1298 \\
(0.0297)\end{array}$ \\
\hline Wage Variability & & & & $\begin{array}{r}1.4438 \\
(0.0532)\end{array}$ & $\begin{array}{r}1.7468 \\
(0.0482)\end{array}$ & $\begin{array}{r}1.6330 \\
(0.0697)\end{array}$ \\
\hline $\begin{array}{l}\text { Nominal Exchange } \\
\text { Rate Variability }\end{array}$ & & & & & $\begin{array}{l}15.5858 \\
(0.4948)\end{array}$ & $\begin{array}{r}15.8405 \\
(0.5054)\end{array}$ \\
\hline Trend & & & & & & $\begin{array}{r}-0.0002 \\
(0.0006)\end{array}$ \\
\hline Trend*Log Distanc & & & & & & $\begin{array}{r}-0.0000 \\
(0.0001)\end{array}$ \\
\hline Trend* Border & & & & & & $\begin{array}{r}-0.0001 \\
(0.0004)\end{array}$ \\
\hline $\begin{array}{l}\text { Log distance } \\
\text { Squared }\end{array}$ & & & & & & $\begin{array}{l}-0.0004 \\
(0.0007)\end{array}$ \\
\hline $\begin{array}{l}\text { Adjusted } R^{2} \\
\text { N. of observations }\end{array}$ & $\begin{array}{r}0.77 \\
5011\end{array}$ & $\begin{array}{r}0.62 \\
3789\end{array}$ & $\begin{array}{r}0.63 \\
3789\end{array}$ & $\begin{array}{r}0.69 \\
3789\end{array}$ & $\begin{array}{r}0.76 \\
3789\end{array}$ & $\begin{array}{r}0.76 \\
3789\end{array}$ \\
\hline
\end{tabular}


Table A1. Correspondence of Japanese and United States Goods

\begin{tabular}{|c|c|c|}
\hline Good & Japanese Prices & U.S. Prices \\
\hline 1 & Canned tuna fish, in oil, \#4 can, $80 \mathrm{~kg}$ & Canned tuna $(6.5 \mathrm{oz})$ \\
\hline 2 & Beef loin $(100 \mathrm{~g})$ & Steak (lb) \\
\hline 3 & Beef shoulder (100g) & Ground Beef (lb) \\
\hline 4 & Chicken, broiler, leg (100g) & Whole Chicken \\
\hline 5 & Bacon, side, $(100 \mathrm{~g})$ & Bacon (lb); Sausage \\
\hline 6 & Fresh milk in carton $(1000 \mathrm{ml})$ & Milk (1/2 gal) \\
\hline 7 & $\begin{array}{l}\text { Processed cheese in carton, } \\
\quad \text { 'Snow brand Hokkaido cheese' ( } 225 \mathrm{~g})\end{array}$ & Parmesan Cheese \\
\hline 8 & Hen eggs, $1 \mathrm{~kg}$ & Eggs (1 dozen, large) \\
\hline 9 & Lettuce, head & Lettuce, head \\
\hline 10 & White potatoes, $1 \mathrm{~kg}$ & Potatoes, white or red \\
\hline 11 & Tomatoes, $1 \mathrm{~kg}$ & $\begin{array}{l}\text { Canned tomatoes, Del Monte or Green } \\
\text { Giant }\end{array}$ \\
\hline 12 & Bananas, $1 \mathrm{~kg}$ & Bananas, (lb) \\
\hline 13 & Margarine, 1 carton & Margarine (lb) \\
\hline 14 & Sugar, white, packaged $1 \mathrm{~kg}$ & Sugar, white, packaged ( $5 \mathrm{lb})$ \\
\hline 15 & Instant coffee & $\begin{array}{l}\text { Ground coffee, (2 lb), Maxwell House, } \\
\text { Folgers }\end{array}$ \\
\hline 16 & $\begin{array}{l}100 \% \text { fruit drinks, Valencia orange juice, } \\
\text { in cartons }(1000 \mathrm{ml})\end{array}$ & Canned orange juice $(6 \mathrm{oz})$ \\
\hline 17 & Cola Drinks, canned, $(350 \mathrm{ml})$ & Soft drink ( 2 ltr) \\
\hline 18 & Whisky, imported & $\begin{array}{l}\text { Liquor (Seagrams } 7 \text { Crown; J\&B } \\
\text { scotch) }\end{array}$ \\
\hline 19 & Wine, 1 bottle & Wine (1.5 liter) \\
\hline 20 & Beer, in restaurant & Beer in store (6 pack) \\
\hline 21 & Tissue (facial), 1 pouch & Facial tissue, 175 count box \\
\hline 22 & $\begin{array}{l}\text { Laundry detergent, for cotton, hemp, rayon and } \\
\text { synthetic fiber, high density, in box }(1.25 \mathrm{~kg})\end{array}$ & $\begin{array}{l}\text { Washing powder (49 oz), Tide, Bold, } \\
\text { or Cheer }\end{array}$ \\
\hline 23 & Men's slacks, denim jeans, 100\% cotton, 29 31" & Jeans, Levis \\
\hline 24 & Men's long sleeve business shirts & Man's shirt, Arrow or Van Heusen \\
\hline 25 & Men's briefs, $100 \%$ cotton, ordinary quality & Men's briefs, package of 3 \\
\hline 26 & Shampoo, Kao Essential, $220 \mathrm{ml}$ & Shampoo, VO-5, $15 \mathrm{oz}$ \\
\hline 27 & Toothpaste, $170 \mathrm{~g}$, Denter Lion & Toothpaste, Crest or Colgate, $6 \mathrm{oz}$. \\
\hline
\end{tabular}


Table A2. List of Japanese and United States Cities

\begin{tabular}{|c|c|c|}
\hline & Japanese Cities & $\underline{\text { U.S.Cities }}$ \\
\hline 1 & Sapporo & Birmingham AL \\
\hline 2 & Aomori & Mobile AL \\
\hline 3 & Morioka & Blythe CA \\
\hline 4 & Sendai & Indio CA \\
\hline 5 & Akita & Palm Springs CA \\
\hline 6 & Yamagata & Denver CO \\
\hline 7 & Fukushima & Lakeland FL \\
\hline 8 & Utsunomiya & Boise ID \\
\hline 9 & Maebashi & Champaign-Urbana IL \\
\hline 10 & Urawa & Peoria IL \\
\hline 11 & Chiba & Ft. Wayne IN \\
\hline 12 & $\mathrm{Ku}$-area of Tokyo & Indianapolis IN \\
\hline 13 & Yokohama & Cedar Rapids IA \\
\hline 14 & Niigata & Lexington KY \\
\hline 15 & Toyama & Louisville KY \\
\hline 16 & Kanazawa & Baton Rouge LA \\
\hline 17 & Fukui & Lafayette LA \\
\hline 18 & Kofu & New Orleans LA \\
\hline 19 & Nagano & Benton Harbor MI \\
\hline 20 & Gifu & Traverse City MI \\
\hline 21 & Shizouka & Columbus MS \\
\hline 22 & Nagoya & St. Jopseph MO \\
\hline 23 & Tsu & St. Louis MO \\
\hline 24 & Otsu & Falls City NE \\
\hline 25 & Kyoto & Hastings NE \\
\hline 26 & Osaka & Omaha NE \\
\hline 27 & Kobe & Reno, Sparks NV \\
\hline 28 & Himeji & Newark NJ \\
\hline 29 & Itami & New York NY \\
\hline 30 & Nara & Hickory NC \\
\hline 31 & Wakayama & Columbus $\mathrm{OH}$ \\
\hline 32 & Tottori & Altoona PA \\
\hline 33 & Matsue & Rapid City SD \\
\hline 34 & Okayama & Vermillion SD \\
\hline 35 & Hiroshima & Chattanooga TN \\
\hline 36 & Yamaguchi & Knoxville TN \\
\hline 37 & Tokushima & Abilene TX \\
\hline 38 & Takamatsu & EL Paso TX \\
\hline 39 & Matsuyama & Ft. Worth TX \\
\hline 40 & Kochi & Houston TX \\
\hline 41 & Fukuoka & Lubbock TX \\
\hline 42 & Saga & Salt Lake city UT \\
\hline 43 & Nagasaki & Charleston WV \\
\hline 44 & Kumamoto & Appleton WI \\
\hline 45 & Oita & Eau Claire WI \\
\hline 46 & Miyazaki & Madison WI \\
\hline 47 & Kagoshima & Oshkosh WI \\
\hline 48 & Naha & Casper WY \\
\hline
\end{tabular}


Table A3:

International vs. Intra-national Shipping Costs

Over Comparable Distance

\begin{tabular}{|c|c|c|c|c|c|c|}
\hline & & & & $\begin{array}{c}\text { Distance } \\
(1,000 \text { miles })\end{array}$ & $\begin{array}{c}\text { Air } \\
\text { (UPS) }\end{array}$ & $\begin{array}{l}\text { Sea/Ground } \\
\text { (US Postal) }\end{array}$ \\
\hline (1) & Boston->Lisbon & & & 3.2 & $\$ 226.50$ & $\$ 34.30$ \\
\hline (2) & DC->Caracus & & & 2.0 & $\$ 401.75$ & $\$ 34.20$ \\
\hline (3) & Average of (1) and (2) & & & 2.6 & $\$ 314.13$ & $\$ 34.20$ \\
\hline (4) & Boston->San Diego & & & 26 & $\$ 95.25$ & $\$ 24.21$ \\
\hline (5) & $\begin{array}{l}\text { Domestic/International } \\
\text { of (4) to (3) }\end{array}$ & Cost & Ratios & 1.0 & 0.30 & 0.71 \\
\hline
\end{tabular}

Notes:

1. UPS Shipping Cost, 20 lb. Package, 24×20x20 inches, Domestic 2 day air, International 4 day air, comparable class service.

Source: http://www.ups.com/using/services/rave/rate.html

2. US Postal Service Postal Cost, 20 lb. Package 24x20x20 inches, Domestic shipment, 45 days; International shipment, 46 weeks. 
Figure 1

Empirical Density Functions of Good-Level Log Real Exchange Rate in 1985

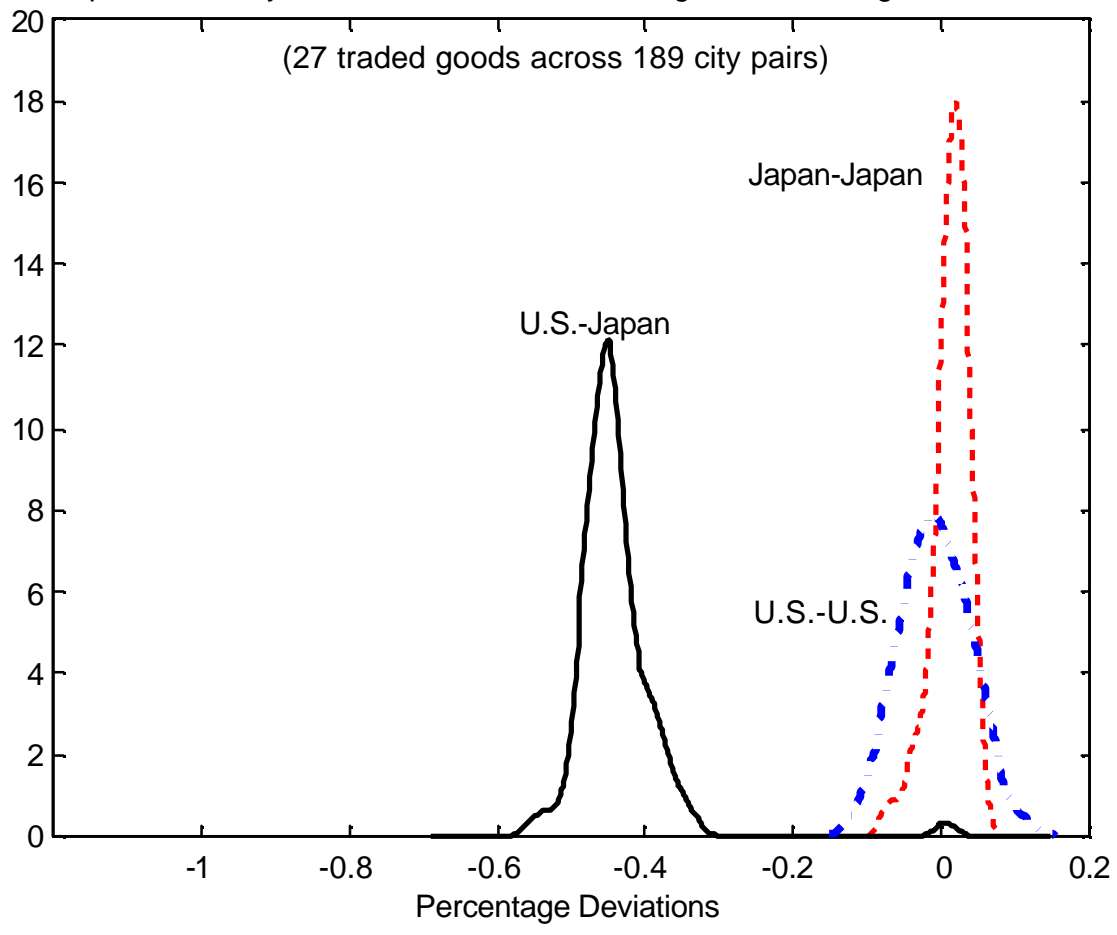

Figure 2

Empirical Density Functions of Good-Level Log Real Exchange Rate in 1990

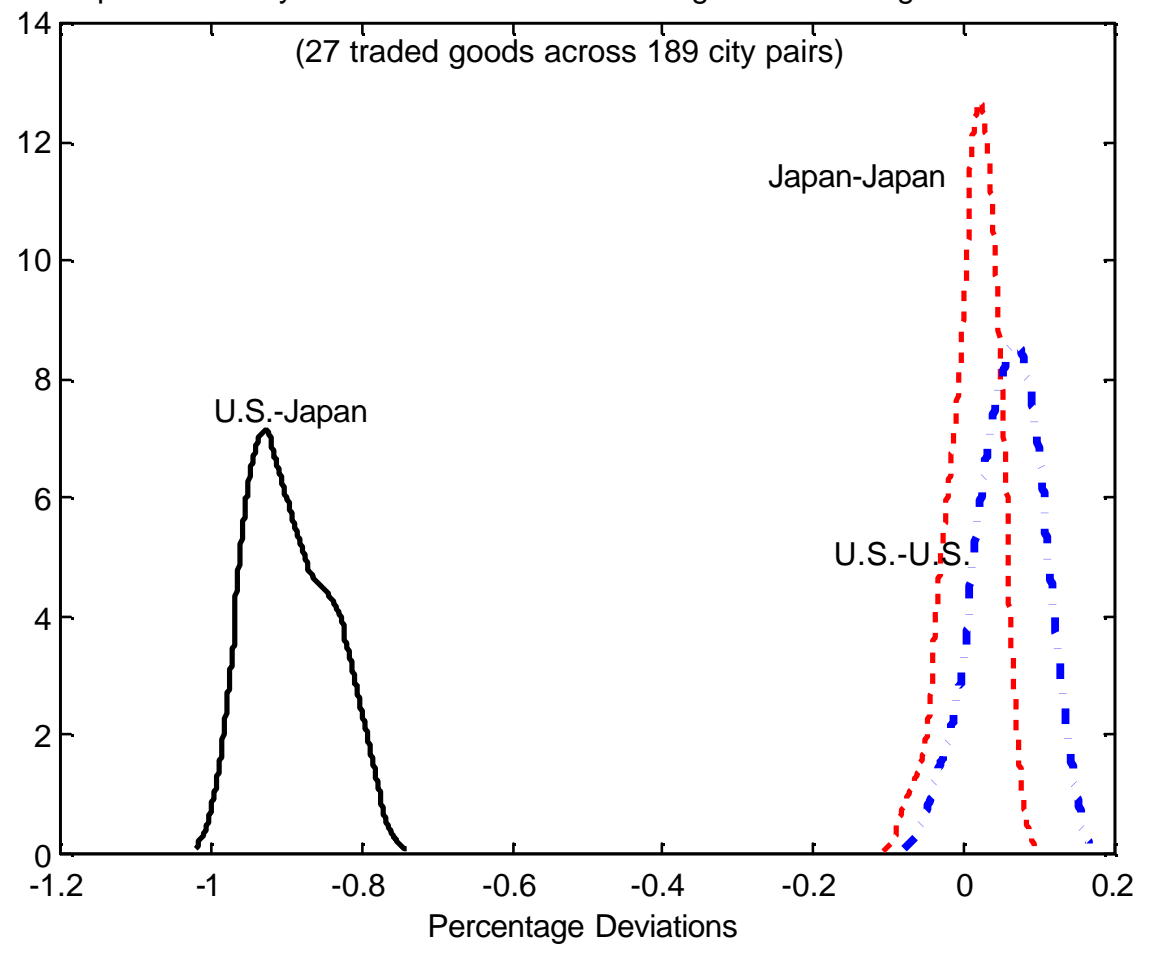


Figure 3: Average of Good-Level Log Real Exchange Rates

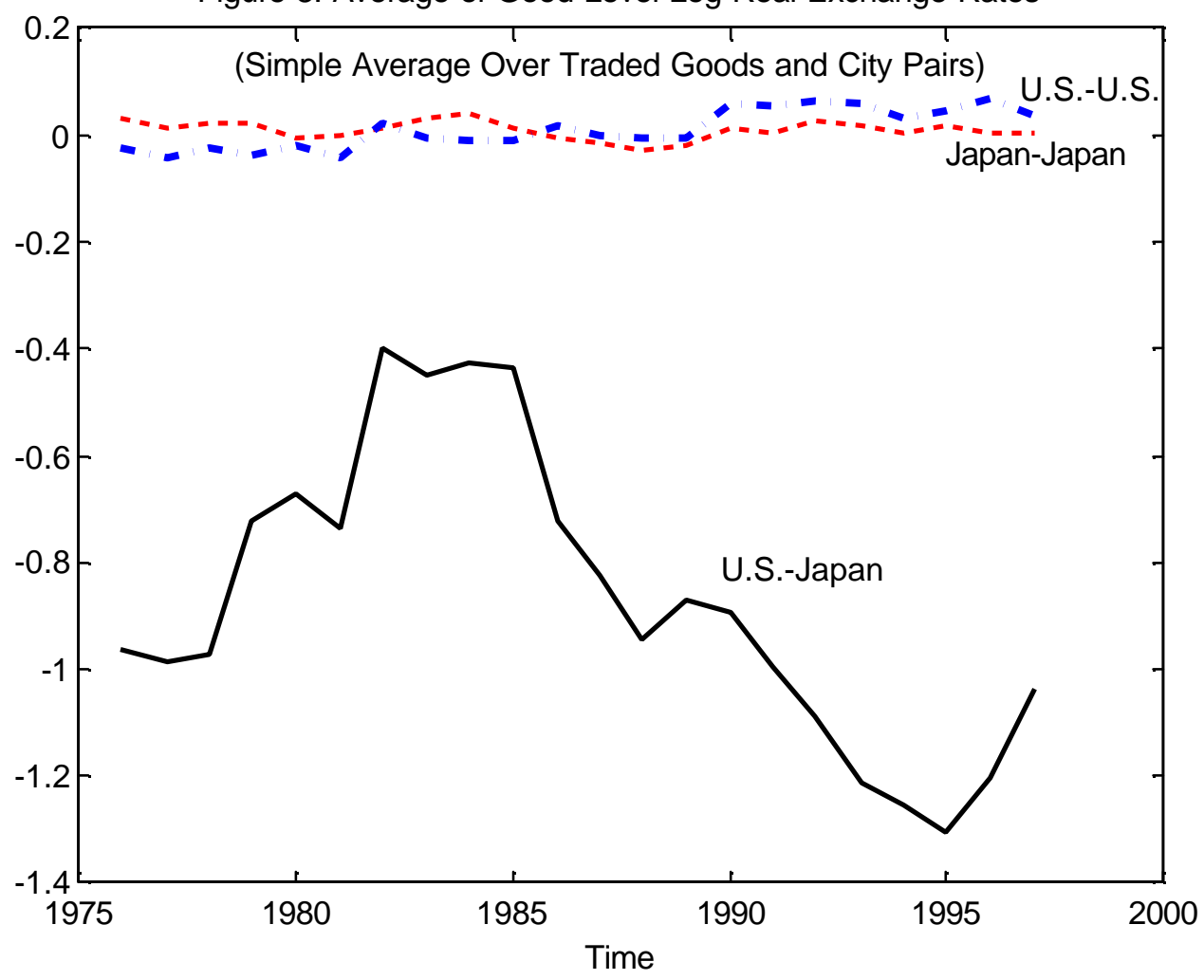

Figure 4: Average of Good-Level Absolute Percentage Deviations

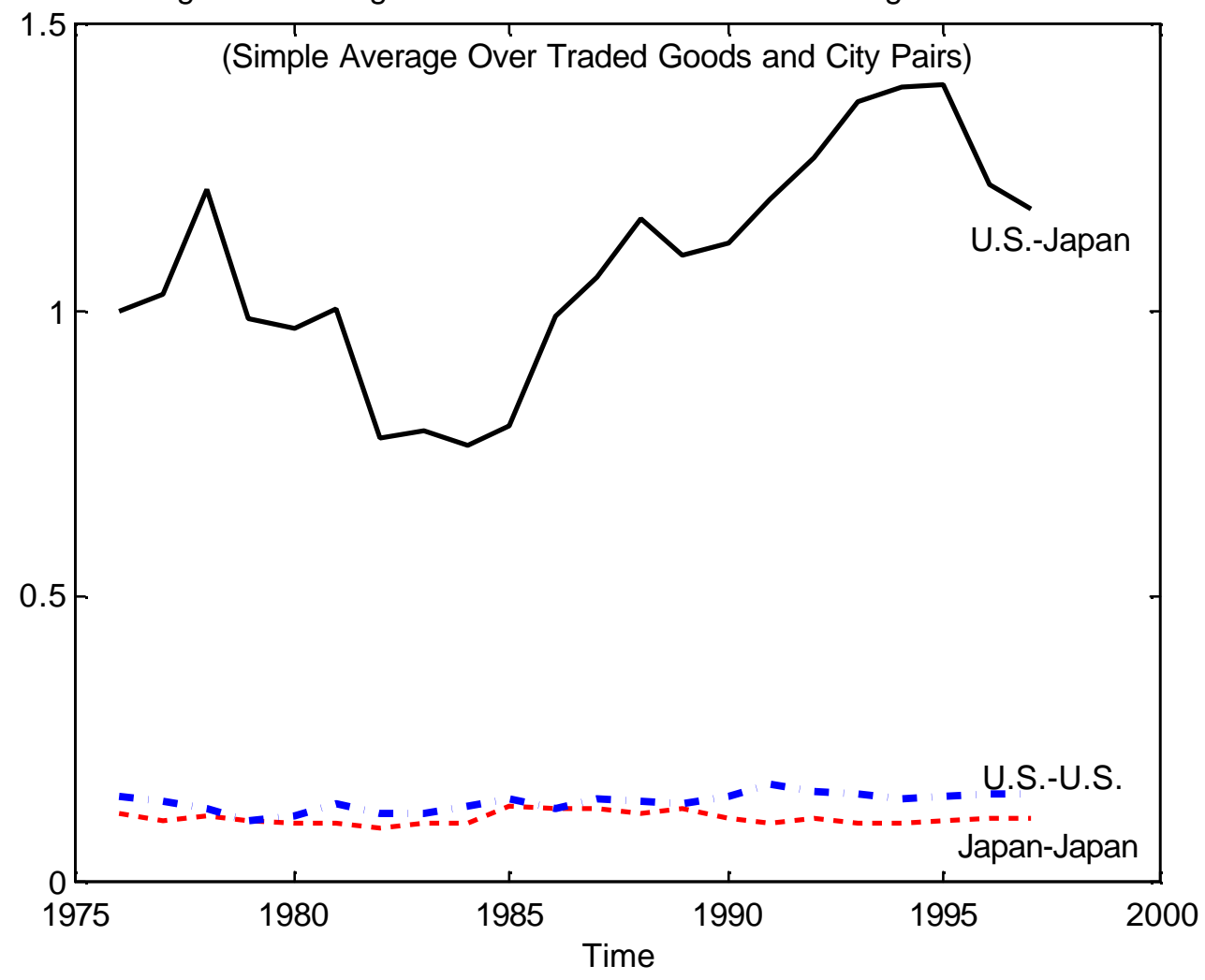




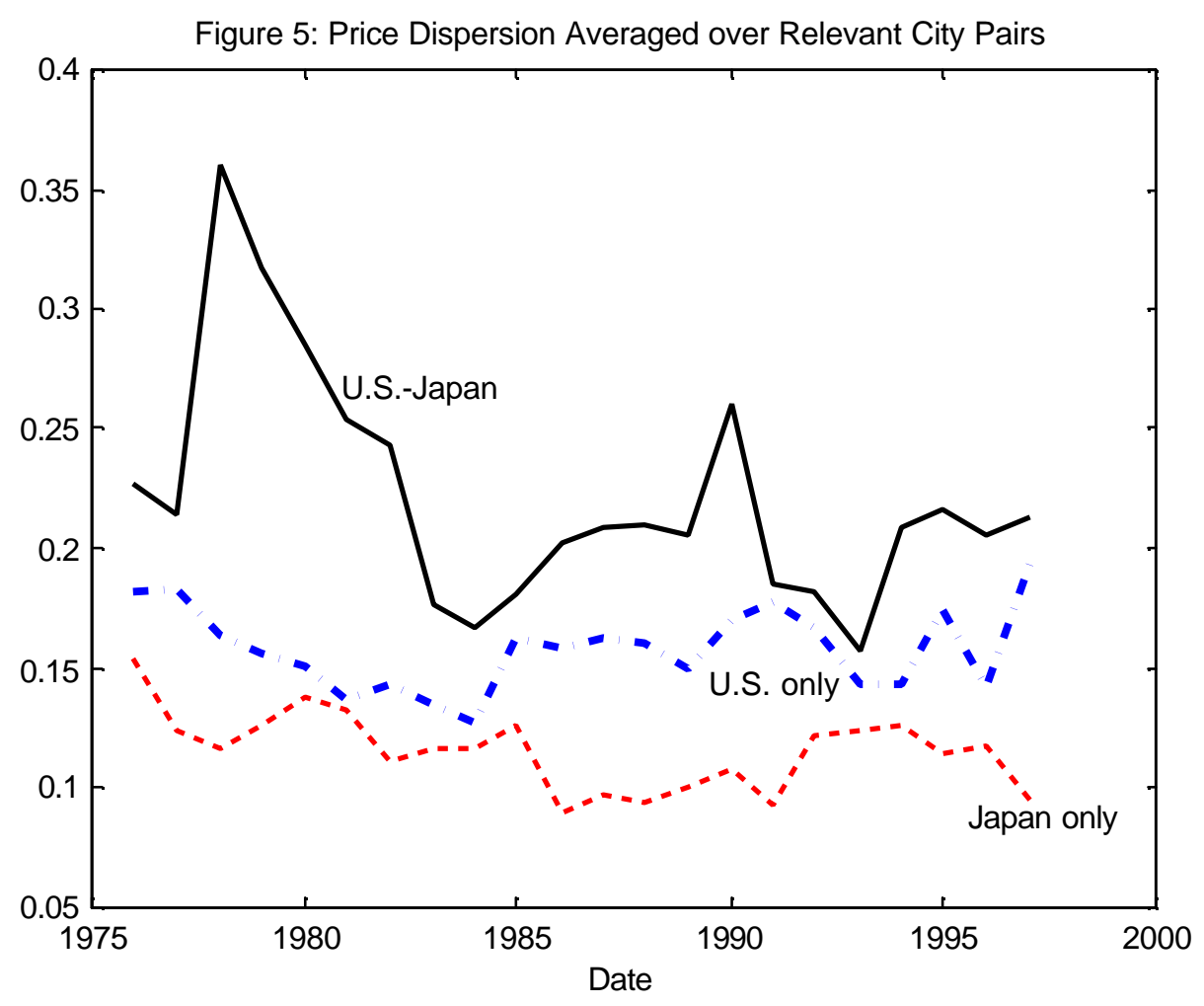

Figure 6a Unit Shipping Costs

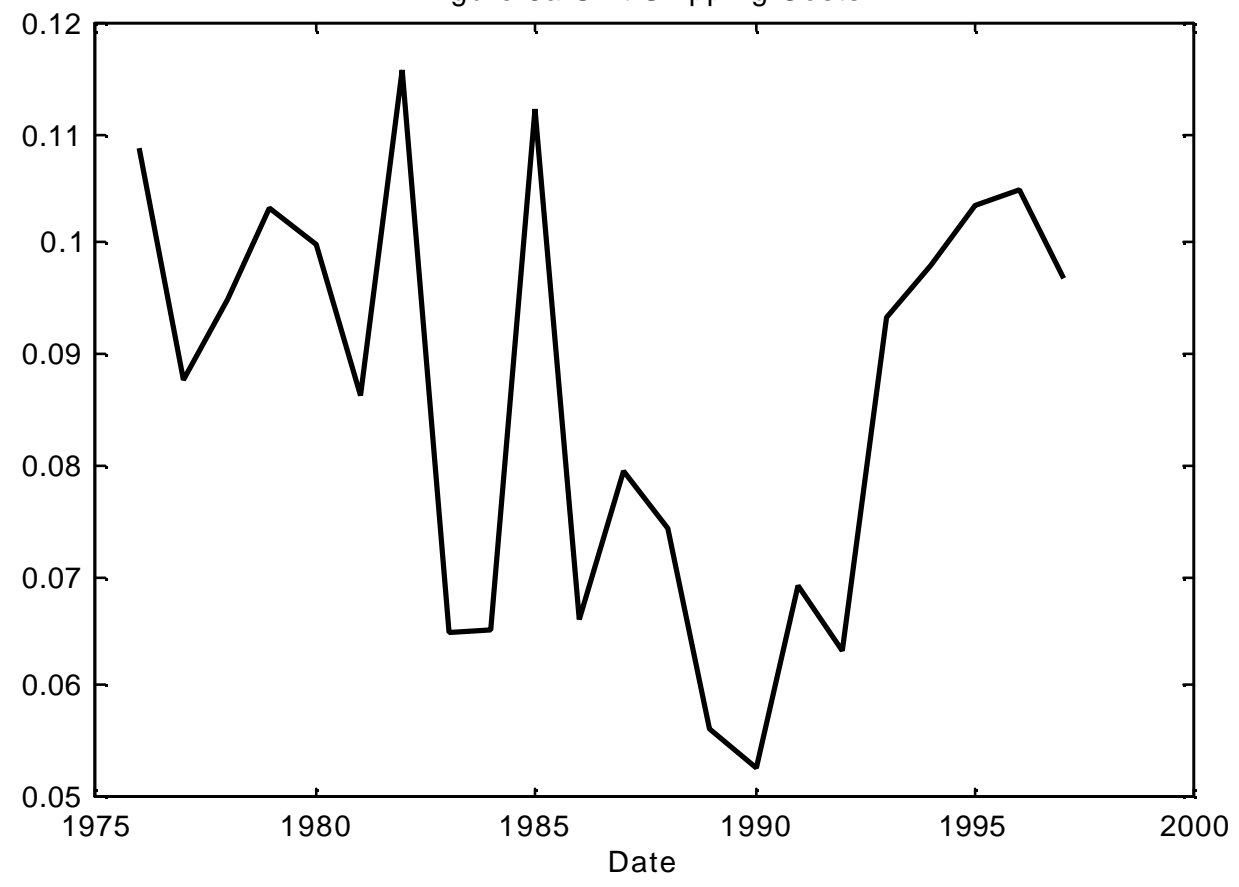




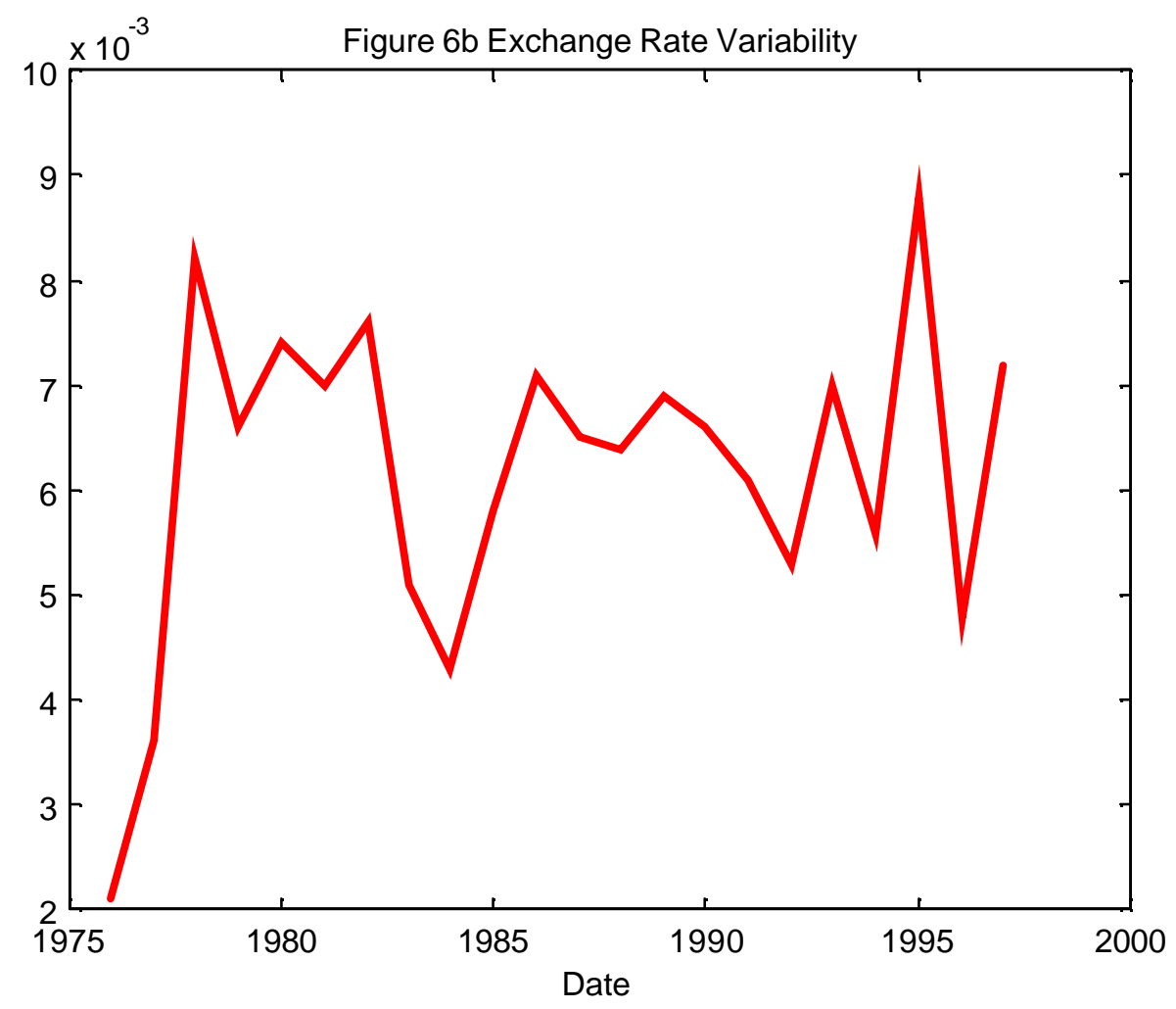

Figure 6c Wage Variability

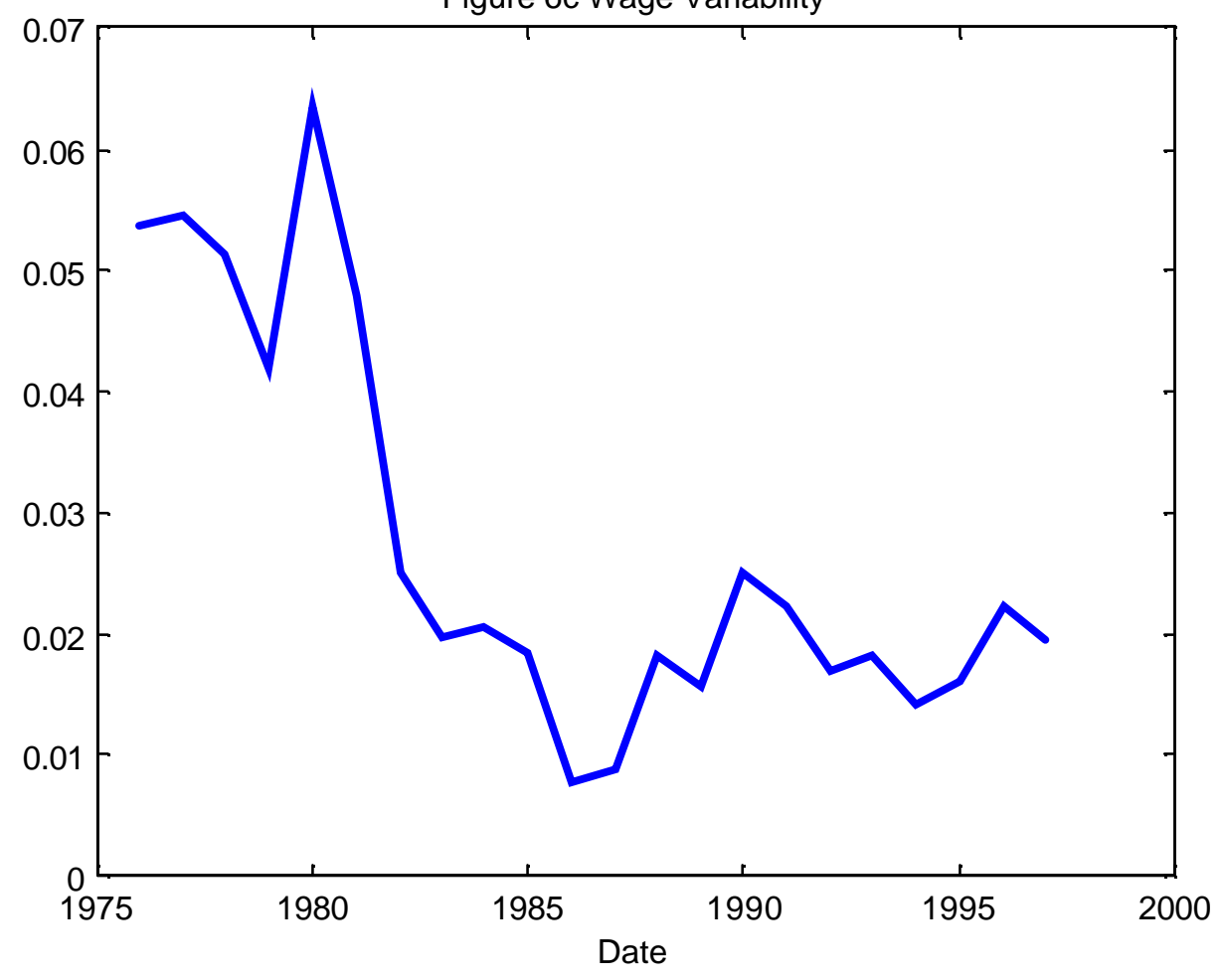

